\title{
Molecular Cloning and Tissue-specific Expression of the Melanocortin 4 Receptor Gene from Olive Flounder, Paralichthys olivaceus
}

\author{
Hye-Jung Lee and Jong-Myoung Kim* \\ Dept. of Marine Biomaterials and Aquaculture, \\ Pukyong National University, Busan 608-737, Korea
}

\begin{abstract}
G protein-coupled receptors (GPCR) constitute the largest superfamily of cell membrane receptors, mediating diverse signal-transduction pathways. The melanocortin 4 receptor (MC4R) has been of interest for its physiological role and size, one of the smallest among the GPCRs, which makes it a good model system for the structural study of GPCRs. To study the molecular structure and tissue-specific expression of MC4R in olive flounder (Paralichthys olivaceus), the full-length MC4R gene was obtained using PCR amplification of genomic DNA as well as cDNA synthesis. Sequence analysis of the gene indicates that $978 \mathrm{bp}$ of the MC4R gene encodes 325 amino acids without introns. Sequence alignment with the MC4Rs from other fish shows the highest degree of identity (96\%) between Paralichthys olivaceous and Verasper moseri, followed by Takifugu rubripes and Tetraodon nigroviridis (89\%). RNA was isolated from various tissues to examine the tissue distribution of MC4R by using RT-PCR. The results showed major expression of MC4R in the liver, brain, and eye, which is consistent with the expression pattern in other fish belonging to the order Pleuronectiformes.
\end{abstract}

Key words: G protein-coupled receptor, Melanocortin 4 receptor, Expression, Olive flounder

\section{Introduction}

$\mathrm{G}$ protein-coupled receptors (GPCRs) which contitute one of the largest superfamilies of membrane receptors, participate in various signaling cascades that couple external signals to internal cellular processes. Upon recognition of a diverse array of extracellular ligands, including neurotransmitters and hormones, and upon receipt of physiological stimuli, such as light, odorants, and some tastants, GPCRs undergo conformational changes, initiating signal transduction cascades through the activation of heterotrimeric G-proteins (Gether, 2000). This in turn activates or inhibits secondary messengers, leading to a variety of physiological responses. Although GPCRs recognize many diverse ligands, all GPCRs share a common topology: seven-transmembrane (7TM) helices, together with some conserved amino acid sequences. GPCRs have been regarded as one of the most attractive targets for drug development, as more than $30 \%$ of drugs on the market are known to

\footnotetext{
*Corresponding author: jongkim@pknu.ac.kr
}

be effective by acting on GPCR signaling. There has been intense research on the structural differences between GPCRs, with and without bound ligand (for reviews, see Smith, 2010; Rosenbaum et al., 2009). Although some structural information at the atomic level has been obtained for the inactive state of GPCRs (Lodowski et al., 2009), detailed information about the structural organization, particularly for the activated state, is still lacking.

Melanocortin receptors (MCRs) belong to the rhodopsin subfamily of GPCRs, one of the largest subfamilies. MCRs are activated by the ligands $\alpha-, \beta-$, and $\gamma$-melanocyte stimulating hormone (MSH) and adrenocorticotropic hormone (ACTH), derived from the precursor pro-opiomelanocortin (POMC), and mediate a variety of signaling pathways. Five subtypes of melanocortin receptors (MC1R-MC5R) have been identified in mammals (Desarnaud et al., 1994; Gantz et al., 1993a; Gantz et al., 1993b; Gantz et al., 1994; Griffon et al., 1994; Labbe et al., 1994; Mountjoy et al., 1992). Melanocortin 1 receptor (MC1R), expressed mainly in melanocytes, is involved in skin- and hair-color determination, in addition to having anti-inflammatory action in 
immunocytes such as leukocytes. MC2R is activated by ACTH and mediates physiological reactions in the adrenal gland. MC3R and MC4R are involved in food intake and energy balance in animals; this was shown by MC3R and MC4R knock-out mice exhibiting hyperphagia, hyperinsulinemia, and maturity-onset obesity that corresponded with agouti obesity syndrome (Huszar et al., 1997; Butler et al., 2000). Administration of MCR agonists, such as MSHs and natural and synthetic compounds, including melanotan II (MT-II), into mice caused a loss of appetite and lean phenotype (Chen et al., 2000). Injection of antagonistic ligands of MC3R and MC4R blocked this effect and lead to weight gain. In addition, MC4R is the most common monogenic determinant of obesity (Leibel, 1997; Leibel et al., 1997) and, therefore, has been regarded as one of the main targets for the treatment of anorexia and obesity. MC5R is distributed throughout the peripheral tissue, although its physiological function is not yet clear (Schiöth, 2001).

Olive flounder, Paralichthys olivaceus, belongs to the family Paralichthyidae of the order Pleuronectiormes. It is one of the major cultured marine fishes in Korea; in 2008, approximately 46,000 tons were produced, according to The Status of Aquaculture of Marine Fishes (MOMAF, 2009). The physiology of olive flounder is an active area of research due to interest in its mass production. The MC4R gene of olive flounder is of particular interest, as it may be involved in the control of body weight and meat quality. In this study, the MC4R gene was isolated by PCR amplification of genomic DNA and cDNA isolated from olive flounder tissues. The tissuespecific expression of MC4R was also analyzed.

\section{Materials and Methods}

\section{Materials}

T4 DNA ligase and the AccuPrep ${ }^{\circledR}$ Genomic DNA Extraction Kit were purchased from Bioneer (Daejeon, Korea). TRI REAGENT ${ }^{\mathrm{TM}}$ was obtained from Sigma (Saint Louis, MO). The PolyATract ${ }^{\circledR}$ mRNA Isolation System, ImProm-II ${ }^{\mathrm{TM}}$ Reverse Transcription System and Wizard ${ }^{\circledR}$ Plus Maxipreps DNA Purification System were purchased from Promega (Madison, WI). Restriction endonucleases were purchased from Bioneer (Daejeon, Korea) and New England Biolabs (Beverly, MA). Kits used for plasmid purification, gel extraction, and PCR purification were purchased from NucleoGen (Seoul, Korea). The DNA Walking Speed $U p^{\mathrm{TM}}$ Premix Kit II was obtained from Seegene (Seoul, Korea). The pGEM $^{\circledR}$-T Easy Vector System was obtained from Promega Corporation (Madison, WI). Oligonucleotides and 5X HiQ-PCR mix were obtained from Genotech (DaeJeon, Korea). The PCR primers used are listed in Table 1.

\section{Isolation of genomic DNA and RNA}

Olive flounder genomic DNA was extracted from $100 \mu \mathrm{L}$ of whole blood using the AccuPrep ${ }^{\circledR}$ Genomic DNA Extraction Kit according to the manufacturer's instructions. Total RNA was extracted from various internal organs including the liver and brains using TRI REAGENT ${ }^{\mathrm{TM}}$ according to the manufacturer's protocol. RNA was analyzed by agarose gel electrophoresis and UV/Vis spectrophotometry, then stored at $-80^{\circ} \mathrm{C}$ until use. The isolation of mRNA was carried out using the PolyATract ${ }^{\circledR}$ mRNA Isolation System according to the manufacturer's protocol.

Table 1. List of oligonucleotide sequences used for the experiment

\begin{tabular}{lll}
\hline Primer & Sequence $\left(5^{\prime} \rightarrow 3^{\prime}\right)$ & Comment \\
\hline MC4RF1 & ATC AAG AGC ATG GAC AAC GT & Partial MC4R \\
MC4RR1 & ATC ATG AGG ATG AGG TGG AG & \\
MCDWF1 & CGC TTG CAC ATG AAG CGC AT & \\
MCDWF2 & AG(G/C) GCG CCA ACA TGA AGG & DNA walking PCR \\
MCDWF3 & GGT GTT CGT GGT GTG CTG G & \\
MCDWR2 & AAG ATG GTG ATG TAG CGG TCG & \\
MCDWR3 & AGC AGG CTG CAG ATG GAC & RT-PCR \\
RTMC4RF & GGA GCT GCA GAT CAT AGA GTC A & \\
RTMC4RR & CTG GAG AAC ATC CTG GTG GTC G & \\
actinF & GAA GAT GGT GAT GTA GCG GTC G & \\
actinR & GCA GGT CAT CAC CAT CGG & \\
\hline
\end{tabular}




\section{Cloning of the melanocortin 4 receptor gene}

The PCR reaction mixture used for the amplification of partial regions of the MC4R gene contained $0.5 \mu \mathrm{g}$ genomic DNA, $0.5 \mu \mathrm{M}$ MC4RF1 and MC4RR1 primers, and 1X HiQ-PCR Mix. The PCR reaction was carried out with an initial denaturation at $95^{\circ} \mathrm{C}$ for $5 \mathrm{~min}$, followed by 30 cycles of $45 \mathrm{~s}$ at $94^{\circ} \mathrm{C}, 45 \mathrm{~s}$ at $55^{\circ} \mathrm{C}$, and 2 min at $72^{\circ} \mathrm{C}$, with a final extension at $72^{\circ} \mathrm{C}$ for $5 \mathrm{~min}$. To obtain the $5^{\prime}$ and 3 '-ends of the olive flounder MC4R gene, DNA walking PCR was conducted using the DNA Walking SpeedUp ${ }^{\mathrm{TM}}$ Premix Kit II. Three forward (pMCDWF1, pMCDWF2, pMCDWF3) and three reverse (pMCDWR1, pMCDWR2, pMCDWR3) primers, corresponding to the sense and anti-sense strands (Table 1) of the MC4R gene, were used to amplify the 5'- and 3'-end regions of the gene, respectively (Table 1 ). The amplified PCR products were cloned into the pGEM $^{\circledR}$-T Easy Vector, transformed into E. coli, and then analyzed by restriction digestion and DNA sequencing. Amplification of the MC4R gene was performed using the first-strand cDNA as a template.

\section{Tissue-specific expression of the MC4R gene analyzed by RT-PCR}

To examine the tissue-specific expression of MC4R in olive flounder, RNA was extracted from various internal organs, including the kidney, gut, gill, liver, intestine, spleen, heart, eye, and brain, as described above. The isolation of mRNA was carried out using the PolyATract ${ }^{\circledR}$ mRNA Isolation System according to the manufacturer's protocol. First-strand cDNA was synthesized using mRNA as a template and oligo $(\mathrm{dT})_{13}$ as a primer using the ImProm- $\mathrm{II}^{\mathrm{TM}}$ Reverse Transcription System. RT-PCR was performed using the first-strand cDNA as a template and specific primers (RTMC4RF, RTMC4RR) derived from the MC4R sequence of olive flounder, as determined in this study. As an internal positive control, PCR amplification of the $\beta$-actin gene was conducted using primers corresponding to the $\beta$-actin gene (actinF and actinR). RT-PCR was performed with a cycle of $3 \mathrm{~min}$ incubation at $95^{\circ} \mathrm{C}$ followed by 25 cycles of $40 \mathrm{~s}$ at $94^{\circ} \mathrm{C}, 40 \mathrm{~s}$ at $60^{\circ} \mathrm{C}$, and $40 \mathrm{~s}$ at $72^{\circ} \mathrm{C}$, with a final extension of $5 \mathrm{~min}$ at $72^{\circ} \mathrm{C}$.

\section{Sequence alignment and phylogenetic analysis}

From the full-length MC4R gene derived from PCR, using the genomic DNA and cDNA as a template, a compiled amino acid sequence was aligned with other known MCR sequences using Clustal W (Thompson et al., 1994). The accession numbers of melanocortin
4 receptor sequences searched in the NCBI GenBank were as follows: Homo sapiens MC4R (NM005912), Mus musculus MC4R (NM016977), Gallus gallus MC4R (AB012211), Squalus acanthias MC4R (AY169401), Danio rerio MC4R (NM173278), Oncorhynchus mykiss MC4R (AY534915), Takifugu rubripes MC4R (AY227794), Tetraodon nigroviridis MC4R (AY332240), Carassius auratus MC4R (AJ534337), and Verasper moseri MC4R (AB287975).

A phylogenetic tree was constructed by the neighbor-joining method using MEGA v 4.0 (Tamura et al., 2007). Accession numbers of other melanocortin receptor sequences selected using BLASTp were Homo sapiens MC3R (NM019888), MC5R (NM005913), Mus musculus MC3R (NM008561), MC5R (013596), Gallus gallus MC3R (AB017137), MC5R (AB012868), Squalus acanthias MC3R (AY560605), MC5R (AY562212), Danio rerio MC3R (NM180972), MC5Ra (AY078990), MC5Rb (AY078991), Takifugu rubripes MC5R (AY227796), and Tetraodon nigroviridis MC5R (AY332241). Tree reliability was assessed using a bootstrap with 1000 replicates. The outgroup was the human melanocortin 1 receptor (AF153431).

\section{Results and Discussion}

\section{Cloning of the MC4R gene}

MC4R belongs to the largest subfamily of GPCRs, the rhodopsin subfamily, which mediate a diverse array of signal transduction pathways. Among GPCRs, MC4R has been a focus of intense research for its association with obesity. It is also regarded as a model system for the structural study of GPCRs, as MC4R is one of the smallest GPCRs, which may favor a relatively stable structure during crystallization. The MC4R gene in olive flounder, one of the major aquaculture species in Korea, is of interest because it is implicated in body-weight control.

Amplification of the MC4R gene was initially carried out using genomic DNA as a template because no introns were found in the coding region of the MC4R gene in other fishes (Klovins et al., 2004). For this purpose, genomic DNA was isolated from the whole blood of olive flounder, as described in the Materials and Methods. A high molecular weight of the genomic DNA, determined by agarose gel electrophoresis, confirmed the integrity of the genomic DNA (data not shown) suitable for amplification. PCR primers (Table 1) were designed from the conserved regions of all known fish MC4R genes (rainbow trout, spiny dogfish, spotted Japanese 
pufferfish, goldfish, zebrafish, and fugu) (Metz et al., 2006). Amplification of the MC4R gene using genomic DNA and the oligonucleotides MC4RF1 and MC4RR1 resulted in a $450 \mathrm{bp}$ fragment (data not shown), as expected from the size of the corresponding regions conserved in other MC4Rs. Sequence analysis of the DNA, as well as the amino acid sequence translated using BlastN and BlastX, revealed a high similarity with other MC4R genes (data not shown). To obtain the full length of the MC4R gene through DNA walking, oligonucleotides corresponding to the sense and antisense regions of the target gene were designed (Table 1). Cloning and sequence analysis of the clones obtained from DNA walking showed amplification of 715-bp and 634-bp fragments, corresponding to the 5'- and 3'-end regions of the gene, respectively (Fig. 1). DNA sequence information based on the analysis of the partial gene products amplified by PCR and DNA walking experiments were compiled to obtain the full-length MC4R gene. The results showed that the full-length MC4R gene in olive flounder consists of 978 base pairs encoding 325 amino acids (Fig. 1). A comparison of the PCR products obtained by amplification of the genomic DNA with those obtained by amplification of the cDNA prepared by using RNA isolated from brain tissue, showed similar sizes within $1 \mathrm{~kb}$, as determined by agarose gel electrophoresis (data not shown). The DNA base sequence of the MC4R gene, as well as the absence of any introns, was confirmed by analysis of the MC4R clones obtained from cDNA amplification.

The amino acid sequence of MC4R was deduced from the full length MC4R gene. Sequence alignment of its amino acids against other known MC4Rs using the Clustal W program showed the highest similarity $(96 \%)$ to MC4R of barfin flounder ( $V$. moseri), followed by fugu $(89 \%)$, zebrafish $(80 \%)$, and human (67\%). The amino acid sequence was also compared with that of other species by the percentage of identity (Fig. 2 and Table 2). The MC4R amino acid sequence is highly conserved even between fish and mammalian orthologs $(65-70 \%)$, in contrast to that of other subtypes of melanocortin receptors, such as MC1R and MC2R (52-53\%) (Schiöth et al., 2005). Hydropathy analysis of its amino sequence predicted seven transmembrane regions, one of the characteristics of GPCRs (Fig. 2). Other characteristics of the MC4R gene of olive flounder included the lack of introns in the putative coding region and the presence of an ERY/DRY motif at the end of the TM3, consistent with all known MC4R genes. Putative Nglycosylation sites were also identified at $\mathrm{Asn}^{2}, \mathrm{Asn}^{15}$,
$\mathrm{Asn}^{95}$, and $\mathrm{Asn}^{109}$. Alignment of the MC4R genes also indicated the presence of the characterized PMY motif in the first intracellular loop, a lack of Pro in TM5 (Ringholm et al., 2002; Cerdá-Reverter et al., 2005), and short extracellular and intracellular loops. In general, the regions corresponding to the seven transmembrane helices were more conserved relative to the $\mathrm{N}$ - and $\mathrm{C}$-terminals, which showed more variability. Concerning the DPXXY motif present at the end of the 7TM region of MC4R, most of the species compared in Fig. 3 exhibited a DPLIY motif, although a DPIIY motif was present in the MC4R of olive flounder, barfin flounder, fugu, and Japanese pufferfish. Teleost fishes appeared about 150 MYA in the late Jurassic period and diverged from the lineage leading to mammals about 400-450 MYA (Schiöth, 2006). Differences in the melanocortins and their receptors have been used to trace the detailed evolutionary relationships amongst the teleosts. A close evolutionary relationship among the teleost species is reflected in the phylogenetic tree (Fig. 3) constructed by comparing MCR sequences using the neighbor-joining method. Moreover, olive flounder MC4R contains fifteen cysteine residues in all ORF regions, corresponding to the same number and residue locations in the MC4Rs of barfin flounder and fugu (Kobayashi et al., 2007). Human MC4R has a similar pattern composed of 15 cysteine residues at similar locations, except for Cys ${ }^{172}$ in human MC4R (residue 172 of the MC4R of barfin flounder, fugu, and olive flounder is serine), which corresponds to $\mathrm{Cys}^{175}$ in the fish species. It is possible that these cysteine residues play an important role in the functioning of MC4Rs, similar to the crucial role played by a disulphide bridge between the EC loops of MC5R in its pharmacology (Schiöth, 2001).

Tissue-specific expression of the MC4R gene in olive flounder was examined using reverse transcription PCR, as shown in Fig. 4. As an internal positive control in the RT-PCR experiments, primers corresponding to the $\beta$-actin gene were included (Fig. 4B). Expression of the MC4R gene was detected in the liver, eye, and brain of olive flounder. Interestingly, expression of the MC4R gene was reported only in the liver from barfin flounder, in which a higher level of expression was observed in fasting fish than in fed fish (Kobayashi et al., 2007). The results indicate that olive flounder and barfin flounder, both of which belong to the order Pleuronectiformes, showed abundant expression in the liver. It is possible that reducing the feeding caused an increase in the expression of the MC4R in the liver because the MC system is associated with liver functions (Yada et al., 


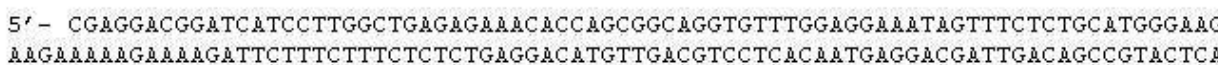
CTGAGACCAGATGGAAMCTAMGGACAGACAMCAGGAGACATT

$\begin{array}{llllllllllllllllllllll}\mathbf{M} & \mathbf{H} & \mathbf{A} & \mathbf{T} & \mathbf{E} & \mathbf{H} & \mathbf{P} & \mathbf{G} & \mathbf{L} & \mathbf{I} & \mathbf{0} & \mathbf{G} & \mathbf{F} & \mathbf{H} & \mathbf{H} & \mathbf{R} & \mathbf{S} & \mathbf{0} & \mathbf{T} & \mathbf{T} & & 2\end{array}$ A T GAA C GCTACA TAA CAT C C T GGA CTGAT C CAAGG C T T CA CAAC CGGAGC CAGACCACG $\begin{array}{lllllllllllllllllllll}\mathbf{P} & \mathbf{S} & \mathbf{P} & \mathbf{H} & \mathbf{E} & \mathbf{D} & \mathbf{F} & \mathbf{S} & \mathbf{A} & \mathbf{0} & \mathbf{D} & \mathbf{K} & \mathbf{D} & \mathbf{S} & \mathbf{S} & \mathbf{A} & \mathbf{G} & \mathbf{C} & \mathbf{Y} & \mathbf{E} & \end{array}$ C CGT CA C CGAACGAGGACTTT T C GC C CAGGACAAGGACTCGTCAGCAGGATGCTACGAG 120 $\begin{array}{lllllllllllllllllllllll}\mathbf{Q} & \mathbf{L} & \mathbf{L} & \mathbf{I} & \mathbf{S} & \mathbf{T} & \mathbf{E} & \mathbf{V} & \mathbf{F} & \mathbf{L} & \mathbf{T} & \mathbf{L} & \mathbf{G} & \mathbf{I} & \mathbf{V} & \mathbf{S} & \mathbf{L} & \mathbf{L} & \mathbf{E} & \mathbf{H} & & 60\end{array}$ CAGCTGCTGAT C T CAC CGAGGTCTT C CT CAC C CTGGGCATCGTCAGC CTG CTGGAGAAC. 180 $\begin{array}{lllllllllllllllllllll}I & \mathbf{L} & \mathbf{V} & \mathbf{V} & \mathbf{A} & \mathbf{A} & \mathbf{I} & \mathbf{I} & \mathbf{K} & \mathbf{H} & \mathbf{K} & \mathbf{H} & \mathbf{L} & \mathbf{H} & \mathbf{S} & \mathbf{P} & \mathbf{M} & \mathbf{Y} & \mathbf{F} & \mathbf{F} & \end{array}$ ATCCT G G G G RTMC4RF

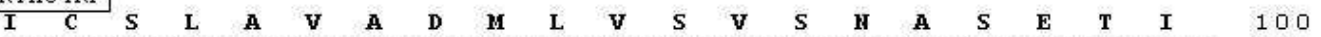
AT CTGCAG C CTTGCCGTTGCTGACATGCTCGTCAGCGTCTCCAACGCCTCTGAGACTATC 300 $\begin{array}{lllllllllllllllllllllllll}\mathbf{V} & \mathbf{I} & \mathbf{A} & \mathbf{L} & \mathbf{I} & \mathbf{H} & \mathbf{G} & \mathbf{G} & \mathbf{H} & \mathbf{L} & \mathbf{T} & \mathbf{I} & \mathbf{P} & \mathbf{V} & \mathbf{T} & \mathbf{L} & \mathbf{I} & \mathbf{K} & \mathbf{S} & \mathbf{M} & 120\end{array}$ GT CAT CGCG CT CAT CAACGGAGGAAA C CTGAC CAT C C C CGTCACGTTGATTAAAAGCATG 360

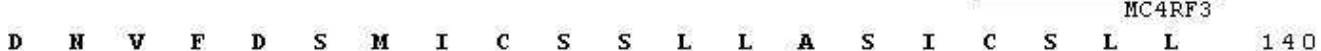
GACAACGTGTTTGACTCTATGATCTGCAGCTCCCTGCTGGCGTCCATCTGCAGCCTGCTC 420

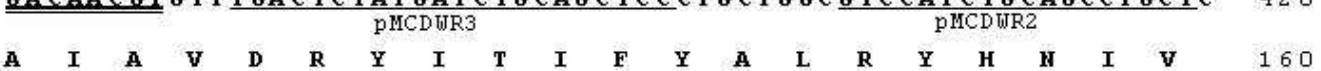
GC CATCGCAGTCGACCGCTACATCACCATCTTCTACGCGCTGCGATACCACAACATCGTC 480

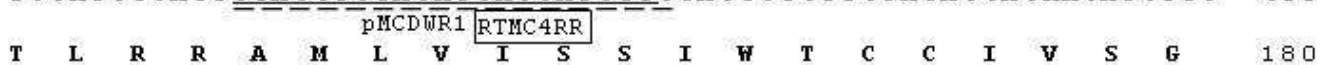
ACGCTGCGGCGGGCGATGCTGGTCATCAGCAGCATCTGGACGTGCTGCATCGTGTCGGGC 540 $\begin{array}{lllllllllllllllllllllll}\mathbf{I} & \mathbf{L} & \mathbf{F} & \mathbf{I} & \mathbf{I} & \mathbf{Y} & \mathbf{S} & \mathbf{E} & \mathbf{S} & \mathbf{T} & \mathbf{T} & \mathbf{V} & \mathbf{L} & \mathbf{I} & \mathbf{C} & \mathbf{L} & \mathbf{I} & \mathbf{T} & \mathbf{M} & \mathbf{F} & 200\end{array}$ AT C CT CTT CAT CAT C TACTCGGAGAGCAC CACGGTG CT CATCTGCCTCATCACCATGTTC 600 $\begin{array}{lllllllllllllllllllllllll}\mathbf{F} & \mathbf{T} & \mathbf{M} & \mathbf{L} & \mathbf{V} & \mathbf{L} & \mathbf{M} & \mathbf{V} & \mathbf{S} & \mathbf{L} & \mathbf{Y} & \mathbf{V} & \mathbf{H} & \mathbf{M} & \mathbf{F} & \mathbf{L} & \mathbf{L} & \mathbf{A} & \mathbf{R} & \mathbf{L} & 220\end{array}$ TT CACCATG CTGGTGCTCATGGTGTCGCTGTACGTGCACATGTTCCTGCTGGCGCGCTTG 660

$\begin{array}{llllllllllllllllllllll}\mathbf{H} & \mathbf{M} & \mathbf{K} & \mathbf{R} & \mathbf{I} & \mathbf{A} & \mathbf{A} & \mathbf{L} & \mathbf{P} & \mathbf{G} & \mathbf{H} & \mathbf{A} & \mathbf{P} & \mathbf{I} & \mathbf{0} & \mathbf{0} & \mathbf{R} & \mathbf{A} & \mathbf{H} & \mathbf{M} & & 2\end{array}$ CACATGAAGCGCATCGCGGCGCTGCCGGGCAACGCG C CATC CAACAGCGAGCCAACATG 720 PMCDWF 1 pMCDWF2 $\begin{array}{llllllllllllllllllllll}\mathbf{K} & \mathbf{G} & \mathbf{A} & \mathbf{I} & \mathbf{T} & \mathbf{L} & \mathbf{T} & \mathbf{I} & \mathbf{L} & \mathbf{L} & \mathbf{G} & \mathbf{V} & \mathbf{F} & \mathbf{V} & \mathbf{V} & \mathbf{C} & \mathbf{H} & \mathbf{A} & \mathbf{P} & \mathbf{F} & 2 & 60\end{array}$ AAGGGCGCCAT CAC C CT CAC CAT C CT C CT CGGGGTGTTCGTGGTGTGCTGGGCGCCGTTT 780 $\begin{array}{lllllllllllllllllllllllll} & \mathbf{L} & \mathbf{L} & \mathbf{H} & \mathbf{L} & \mathbf{I} & \mathbf{L} & \mathbf{M} & \mathbf{I} & \mathbf{T} & \mathbf{C} & \mathbf{P} & \mathbf{R} & \mathbf{H} & \mathbf{P} & \mathbf{Y} & \mathbf{C} & \mathbf{T} & \mathbf{C} & \mathbf{F} & \mathbf{M} & 280\end{array}$ T T C CTCACCTCATCCTCATGAT CACGTGC C CGAGAAC CCGTACTGCACCTGCTTCATG 840

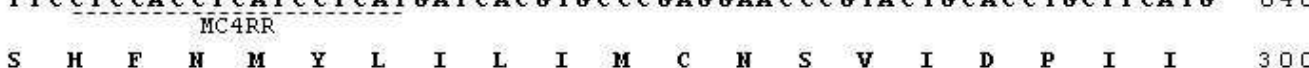

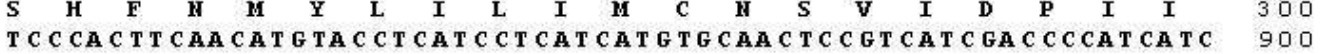
$\begin{array}{llllllllllllllllllllll}\mathbf{Y} & \mathbf{A} & \mathbf{F} & \mathbf{R} & \mathbf{S} & \mathbf{0} & \mathbf{E} & \mathbf{M} & \mathbf{R} & \mathbf{K} & \mathbf{T} & \mathbf{F} & \mathbf{K} & \mathbf{E} & \mathbf{I} & \mathbf{F} & \mathbf{C} & \mathbf{C} & \mathbf{S} & \mathbf{H} & 320\end{array}$ TACGC CTT C CGCAG C CAGGAAATGAGGAAAAC CT T CAAGGAGATTTTCTGCTGCTCAAAC 960 $\begin{array}{llllllll}\text { A L } & \text { L } & \text { C } & \text { * } & 325\end{array}$ G C T C T G C T GT GT T T T GA GACGTCAGCAGAGCGACGGCCTTGACGGCA ACGATCTGCAGTTT \& ATGCCGGTCGGCCA ACGAGG ACTTTGATGTTTCG AGCTGCTCTCACAGTCGCTGTAAMTGATTATGATTGCAGCGTTTGCCTGTGGCGCCGTGAGTCAGGGTTCCGAGGGGGG AAGGTTTACAAACAGCTTCTGACCTGGAGCGTCGCTCTGCAGGCGAACGCTGCGACTGCTCTGCTGCTCTCAAGTGCAAT

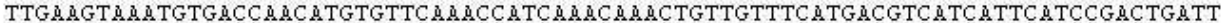
CTTTCTACTTTCACGTGTTCAMAT-3,

Fig. 1. Nucleotide and predicted amino acid sequences of the MC4R gene isolated from olive flounder, Paralichthys olivaceus, together with 5'- and 3'- flanking sequences (GenBank Accession number HQ230046). The complete open reading frame sequence of MC4R was indicated as bold letters together with the stop codon as indicated by an asterisk $(*)$.

2000; Kobayashi et al., 2007). Other tissues showing expression of the MC4R gene included the eye and brain, but little expression occurred in the intestine, spleen, kidney, heart, gut, or gill. While most mammalian MC4R expression was detected only in the brain (Adan et al., 2006), others reported expression of MC4R in the peripheral tissues of rainbow trout (Haitina et al., 2004) and in the chicken 


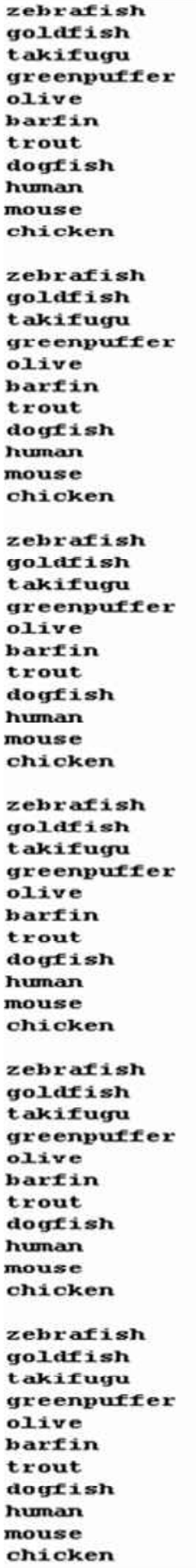

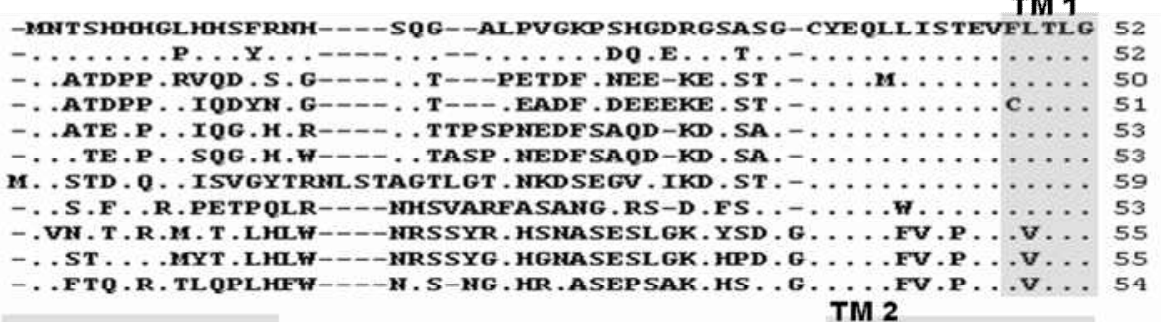

LVSLLENILVIAATVKOKKILHSPAYFFICSLAVADLLVSVSWASETVVMALTTGGNLTHR 112

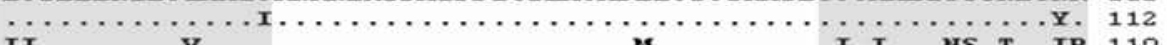

Fig. 2. Alignment of MC4Rs from olive flounder together with zebrafish, goldfish, fugufish, greenpufferfish, barfin flounder, rainbow trout, spiny dogfish, human, mouse, chicken. Conserved sequences indicate as dots. Regions corresponding to the seven transmembranes are indicated by shadow boxes. DRY motif is indicated as square box and DPXXY motif is indicated as oval shape.

(Ringholm et al., 2002; Takeuchi et al., 1998; Teshigawara et al., 2001). However, the putative MC4R of lamprey, an extant jawless fish, was ex- pressed in the skin, liver, heart and skeletal muscle, but not in the brain (Haitina et al., 2007). Thus, the expression pattern of the MC4R gene in fish may suggest 
Table 2. Percentage identity of the MC4R amino acid sequences among different species. hMC: human MC4R, mMC: mouse MC4R, cMC: chicken MC4R, dMC: spiny dogfish MC4R, zMC: zebrafish MC4R, tMC: rainbow trout MC4R, fMC: fugu MC4R, pMC: pufferfish MC4R, gMC: goldfish MC4R, oMC: olive flounder MC4R, bMC4: barfin flounder MC4R

\begin{tabular}{|c|c|c|c|c|c|c|c|c|c|c|c|}
\hline & $\mathrm{hMC}$ & $\mathrm{mMC}$ & cMC & $\mathrm{dMC}$ & $\mathrm{zMC}$ & $\mathrm{t} M \mathrm{C}$ & $\mathrm{fMC}$ & $\mathrm{pMC}$ & $\mathrm{gMC}$ & $\mathrm{OMC}$ & $\mathrm{bMC}$ \\
\hline $\mathrm{hMC}$ & 100 & 93 & 87 & 70 & 69 & 68 & 66 & 65 & 70 & 67 & 68 \\
\hline $\mathrm{mMC}$ & & 100 & 85 & 67 & 70 & 69 & 65 & 66 & 69 & 68 & 67 \\
\hline cMC & & & 100 & 67 & 68 & 71 & 65 & 65 & 67 & 68 & 68 \\
\hline $\mathrm{dMC}$ & & & & 100 & 77 & 74 & 73 & 72 & 73 & 74 & 73 \\
\hline $\mathrm{zMC}$ & & & & & 100 & 78 & 76 & 78 & 96 & 80 & 80 \\
\hline tMC & & & & & & 100 & 78 & 79 & 78 & 82 & 80 \\
\hline $\mathrm{fMC}$ & & & & & & & 100 & 94 & 76 & 89 & 88 \\
\hline $\mathrm{pMC}$ & & & & & & & & 100 & 77 & 89 & 88 \\
\hline gMC & & & & & & & & & 100 & 78 & 79 \\
\hline OMC & & & & & & & & & & 100 & 96 \\
\hline $\mathrm{bMC}$ & & & & & & & & & & & 100 \\
\hline
\end{tabular}

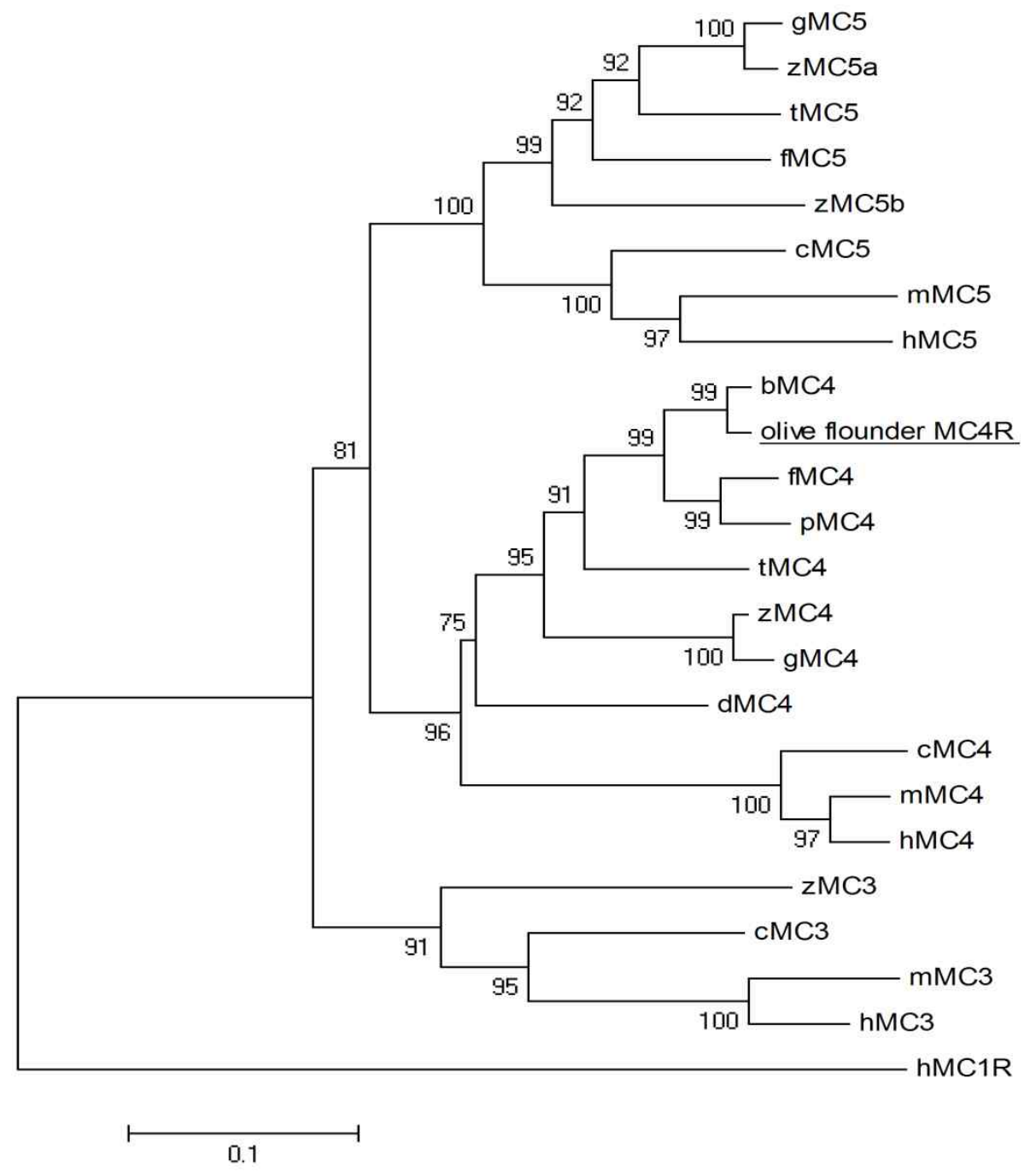

Fig. 3. Phylogenetic tree for the MC receptors using comparison of the full-length amino acid sequences. hMC: human MCR, mMC: mouse MCR, cMC: chicken MCR, fMC: fugu MCR, pMC: pufferfish MCR, zMC: zebrafish MCR, gMC: goldfish MCR, tMC: rainbow trout MCR, dMC: spiny dogfish MCR, bMC4: barfin flounder MC4R. 


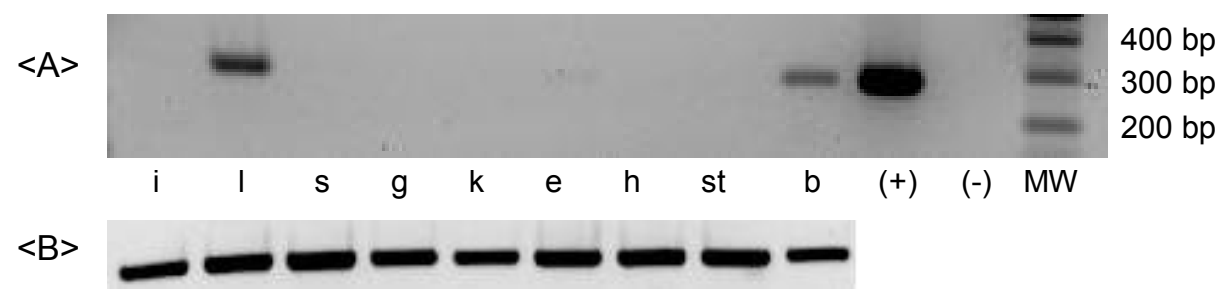

Fig. 4. Analysis of $\mathrm{MC} 4 \mathrm{R}<\mathrm{A}>$ and $\beta$-actin $<\mathrm{B}>$ gene expression in various tissues of olive flounder (Paralichthys olivaceus) by using RT-PCR as described in Methods. RNAs were isolated from various tissues as follows : i; intestine, l; liver, s; spleen, g; gill, k; kidney, e; eye, h; heart, st; stomach, b; brain, (+); positive control, olive flounder genomic DNA, (-); negative control, water. MW; DNA 100 bp ladder.

a broader role for the receptor during early vertebrate evolution. It seems that the specific role of MC4R in the central nervous system has undergone evolutional development. This also suggests an evolutionary cleavage in the central function of MCRs as the agnathans and gnathostomes diverged.

\section{Acknowledgements}

This research was a part of the project No. 20088033-1 funded by the Ministry of Land, Transport and Maritime Affairs, Korea.

\section{References}

Adan RA, Tiesjema B, Hillebrand JJ, la Fleur SE, Kas MJ and de Krom M. 2006. The MC4 receptor and control of appetite. Br J Pharmacol 149, 815-27.

Butler AA, Kesterson RA, Khong K, Cullen MJ, Pelleymounter MA, Dekoning J, Baetscher M and Cone RD. 2000. A unique metabolic syndrome causes obesity in the melanocortin-3 receptor-deficient mouse. Endocrinology 141, 3518-21.

Cerdá-Reverter JM, Ringholm A, Schiöth HB, and Peter RE. 2003. Molecular cloning, parmacological characterization, and brain mapping of the melanocortin 4 receptor in the goldfish: Involvement in the control of food intake. Endocrinology 144, 2336-49.

Chen AS, Metzger JM, Trumbauer ME, Guan XM, Yu H, Frazier EG, Marsh DJ, Forrest MJ, Gopal-Truter S, Fisher J, Camacho RE, Strack AM, Mellin TN, MacIntyre DE, Chen HY and Van der Ploeg LH. 2000. Role of the melanocortin-4 receptor in metabolic rate and food intake in mice. Transgenic Res 9, 145-54.

Desarnaud F, Labbe O, Eggerickx D, Vassart G and Parmentier M. 1994. Molecular cloning, functional expression and pharmacological characterization of a mouse melanocortin receptor gene. Biochem J 299, 367-73.

Fan W, Boston BA, Kesterson RA, Hruby VJ and Cone RD. 1997. Role of melanocortinergic neurons in feeding and the agouti obesity syndrome. Nature 385, 165-8.

Gantz I, Konda Y, Tashiro T, Shimoto Y, Miwa H, Munzert G, Watson SJ, DelValle J and Yamada T. 1993a. Molecular cloning of a novel melanocortin receptor. J Biol Chem 268, 8246-50.

Gantz I, Miwa H, Konda Y, Shimoto Y, Tashiro T, Watson SJ, DelValle J and Yamada T. 1993b. Molecular Cloning, Expression, and Gene Localization of a Fourth Melanocortin Receptor. J Biol Chem 268, 15174-9.

Gantz I, Shimoto Y, Konda Y, Miwa H, Dickinson CJ and Yamada T. 1994. Molecular cloning, expression, and characterization of a fifth melanocortin receptor. Biochem Biophys Res Commun 200, 1214-20.

Gether U. 2000. Uncovering Molecular mechanisms involved in activation of $\mathrm{G}$ protein-coupled receptors. Endocr Rev 21, 90-113.

Griffon N, Mignon V, Facchinetti P, Diaz J, Schwartz JC and Sokoloff P. 1994. Molecular cloning and characterization of the rat fifth melanocortin receptor. Biochem Biophys Res Commun 200, 1007-14.

Haitina T, Klovins J, Andersson J, Fredriksson R, Lagerstoröm MC, Larhammar D, Larson ET and Schiöth HB. 2004. Cloning, tissue distribution, pharmacology and three-dimensional modelling of melanocortin receptors 4 and 5 in rainbow trout suggest close evolutionary relationship of these subtypes. Biochem J 380, 475-86.

Haitina T, Klovins J, Takahashi A, Löwgren M, Ringholm A, Enberg J, Kawauchi H, Larson ET, Fredriksson R and Schiöth HB. 2007. Functional characterization of two melanocortin (MC) receptors in lamprey showing orthology to the MC1 and MC4 receptor subtypes. BMC Evol Biol 7, 101A.

Huszar D, Lynch CA, Fairchild-Huntress V, Dunmore JH, Fang Q, Berkemeier LR, Gu W, Kesterson RA, Boston BA, Cone RD, Smith FJ, Campfield LA, Burn $P$ and Lee F. 1997. Targeted disruption of the melanocortin 4 receptor results in obesity in mice. Cell 88, 131-41.

Klovins J, Haitina T, Fridmanis D, Kilianova Z, Kapa I, 
Fredriksson R, Gallo-Payet N and Schiöth HB. 2004. The melanocortin system in Fugu: Determination of POMC/AGRP/MCR gene repertoire and synteny, as well as pharmacology and anatomical distribution of the MCRs. Mol Biol Evol 21, 563-79.

Kobayashi Y, Tsuchiya K, Yamanome T, Schiöth HB, Kawauchi H and Takahashi A. 2008. Food deprivation increases the expression of melanocortin4 receptor in the liver of barfin flounder, Verasper moseri. Gen Comp Endocrinol 155, 280-7.

Labbé O, Desarnaud F, Eggerickx D, Vassart G, and Parmentier M. 1994. Molecular cloning of a mouse melanocortin 5 receptor gene widely expressed in peripheral tissues. Biochemistry 33, 4543-9.

Leibel RL. 1997. Single gene obesities in rodents: possible relevance to human obesity. J Nutr 127:1908S.

Leibel RL, Chung WK and Chua SC Jr. 1997. The molecular genetics of rodent single gene obesities. J Biol Chem 272, 31937-40.

Lodowski DT, Angel TE and Palczewski K. 2009. Comparative Analysis of GPCR Crystal Structures. Photochem Photobiol 85, 425-30.

Metz JR, Peters JJ and Flik G. 2006. Molecular biology and physiology of the melanocortin system in fish: A review. Gen Comp Endocrinol 148, 150-62.

Mountjoy KG, Robbins LS, Mortrud MT and Cone RD. 1992. The cloning of a family of genes that encode the melanocortin receptors. Science 257, 1248-51.

Ringholm A, Fredriksson R, Poliakova N, Yan YL, Postlethwait JH, Larhammar D and Schiöth HB. 2002. One melanocortin 4 and two melanocortin 5 receptors from zebrafish show remarkable conservation in structure and pharmacology. J Neurochem 82, 6-18.

Rosenbaum DM, Rasmussen SG and Kobilka BK. 2009. The structure and function of $G$ Protein-coupled receptors. Nature 459, 356-63.

Sambrook J and Russell DW. 2001. Molecular cloning: A laboratory manual. 3rd edition. Cold Spring Harbor Laboratory Press, NY, Plainview.

Schiöth HB. 2001. The physiological role of melanocortin receptors. Vitamins Hormones 63, 195-232.

Schiöth HB, Haitina T, Ling MK, Ringholm A, Fredrikson R, Cerda-Reverter JM and Klovins J. 2005. Evolutionar conservation of the structural, pharma-cological, and genomic characteristics of the melanocortin receptor subtypes. Peptides 26, 1886-900.

Schiöth HB. 2006. G protein-coupled receptors in regulation of body weight. CNS Neurol Disord Drug Targets 5, 241-9.

Smith SO. 2010. Structure and activation of the visual pigment rhodopsin. Ann Rev Biophys 39, 309-28.

Takeuchi S and Takahashi S. 1998. Melanocortin receptor genes in the chicken tissue distributions. Gen Comp Endocrinol 112, 220-31.

Tamura K, Dudley J, Nei M and Kumar S. 2007. MEGA4: Molecular Evolutionary Genetics Analysis (MEGA) software version 4.0. Mol Biol Evol 24, 1596-9.

Teshigawara K, Takahashi S, Boswell T, Li Q, Tanaka S and Takeuchi S. 2001. Identification of avian alphamelanocyte-stimulating hormone in the eye: Temporal and spatial regulation of expression in the developing chicken. J Endocrinol 168, 527-37.

Thompson JD, Higgins DG and Gibson TJ. 1994. CLUSTAL W: Improving the sensitivity of progressive multiple sequence alignment through sequence weight matrix choice. Nucleic Acids Res 22, 4673-80.

Yada T, Azuma T, Takahashi A, Suzuki Y and Hirose S. 2000. Effects of desacetyl $\alpha$-MSH on lipid mobilization in the rainbow trout, Oncorhynchus mykiss. Zool Sci 17, 1123-7.

(Received 28 Sepetember 2010; Revised 8 November 2010; Accepted 5 December 2010) 